\title{
Ornamental Growers' Water Use and Conservation Practices in Miami-Dade County 1
}

\author{
Rafael Muñoz-Carpena, Jonathan H. Crane, Glenn D. Israel, and Joe Garofalo²
}

\section{Introduction and background}

The Miami-Dade County ornamental nursery industry employs over 6,300 people and has a $\$ 440$ million dollar sales impact on the state economy (Degner et al., 2002a). However, a recent update reported the total economic impact of the ornamentals industry of Miami-Dade County at about $\$ 790$ million with an employment impact at over 18,000 jobs (Hodges and Haydu, 2000). There are about 12,010 acres of nursery production in Miami-Dade County consisting of three general types of nurseries: a) field nurseries, b) container nurseries and, c) shade or greenhouse nurseries. The estimated number of nursery producers ranges from 573 to 1053 depending upon the criteria and sources used to estimate it (Degner et al., 2001b; Hodges and Haydu, 2000; J. Garofalo and C. Yurgalevitch, personal communication).

The major issues facing the ornamental nursery industry in Florida, include marketing and foreign competition, land use planning, water and fertilizer management, pests and diseases, natural disaster avoidance and mitigation, and sustainable cultural practices. Due to the on-going Everglades and Biscayne National Park restoration projects, water and fertilizer management practices for the ornamental industry have become critical components of its sustainability.

Water use, management, and quality are major issues in Florida's Miami-Dade County where periods of excessive rainfall (flooding) and extended dry spells (drought) are experienced occasionally. Agricultural practices (e.g., irrigation and fertilizer management) potentially affect the water quality of the Biscayne Aquifer and Biscayne Bay. However, water conservation practices by the Miami-Dade County ornamental nursery industry are largely undocumented.

This fact sheet reports water conservation trends for ornamental nursery producers based on a recent extensive survey carried out in Miami-Dade County.

1. This document is Fact Sheet ABE347, one of a series of Agricultural and Biolgoical Engineering Department, Florida Cooperative Extension Service, Institute of Food and Agricultural Sciences, University of Florida. Published December 2003. Please visit the EDIS web site at http://edis.ifas.ufl.edu.

2. R. Muñoz-Carpena, Asst. Prof., Hydrologist, and J.H. Crane, Prof., Tropical Fruit Crops Specialist, Tropical Research and Education Center, Homestead, FL; G.D. Israel, Prof., Agricultural Education and Communication Dept., Gainesville, FL and; J. Garofolo, Commercial Ornamentals Extension Agent, Miami-Dade County Cooperative Extension Service, Homestead, FL: Cooperative Extension Service, Institute of Food and Agricultural Sciences, University of Florida, Gainesville, 32611.

The Institute of Food and Agricultural Sciences is an equal opportunity/affirmative action employer authorized to provide research, educational information and other services only to individuals and institutions that function without regard to race, color, sex, age, handicap, or national origin. For information on obtaining other extension publications, contact your county Cooperative Extension Service office. Florida Cooperative Extension Service/Institute of Food and Agricultural Sciences/University of Florida/Christine Taylor Waddill, Dean. 


\section{Survey and analysis methodology}

The survey involved a random sample of 573 ornamental nursery producers that were selected from mailing lists obtained from the Miami-Dade County/IFAS Cooperative Extension Service and growers' organizations in Miami-Dade County. The survey recipients were selected according to the size of their operation to obtain a maximum of 319 surveys with a range in the sizes of operations. This represents close to 30 to $55 \%$ of the sampled population (depending of source accepted for total number of growers).

The survey instrument contained questions concerning current water consumption and irrigation practices, motivations for their adoption by growers, issues affecting water use, drought and flooding experience, and water management. Questions related to when the grower first started farming and the size of the farm were added to gain a perspective of changes in the area with time.

The survey procedures were tailored to maximize growers' participation (Dillman, 2000). Each potential respondent received a letter informing him or her of the purpose of the survey. Two weeks later the surveys were sent out, and telephone follow-up was done 4 and 8 weeks later. The survey protocol was designed to collect enough responses for statistical analysis of the influence of the economic, technical, and sociological factors on water conservation practices in the area. The survey data were analyzed using SAS software FREQ and MEANS statistical procedures (SAS, 1999).

\section{Survey results}

\section{Background}

Although an initial random sample of over 390 surveys was sent out, some growers could not be contacted or were no longer in business. Of the 319 growers who were in the reachable sample, 65 returned usable surveys. The survey response rate was $20 \%$, representing $10 \%$ of the ornamentals crop acreage and $11 \%$ of the estimated 573 commercial ornamental growers. Mail-back survey response rates of 10 to $50 \%$ are common and typically may be as low as 20\% (Donan et al., 2000; Nachmias and Nachmias, 1976; Neuman, 1997).

Ornamental nurseries averaged about 19 acres with most operators (88\%) owning their land, $8 \%$ leasing, and someone other than the owner managing $4 \%$. Over half $(53 \%)$ the responding ornamental nurseries reported they had irrigation systems. This probably reflected mostly containerized plant operations as opposed to field nurseries with plants in the ground.

\section{Changes in irrigation technology}

There have been dramatic changes in irrigation system technology, and soil water content monitoring during the past 18 years, which is the average time survey respondents have been in business. Generally, irrigation efficiencies have been improved in nursery operations by more direct water delivery systems that limit the application rate and land surface area irrigated (e.g., drip, microsprinkler) and by the use of soil water content monitoring devices (e.g., tensiometers) that enable producers to reduce leaching and apply water based solely on crop needs.

There was relatively little change in the use of high volume irrigation (high volume overhead, high volume under plant) by the nursery industry $(84 \%$ before, $89.0 \%$ now) (Fig. 1). This is a reflection of the need for these systems in freeze protection, especially in field nursery situations.

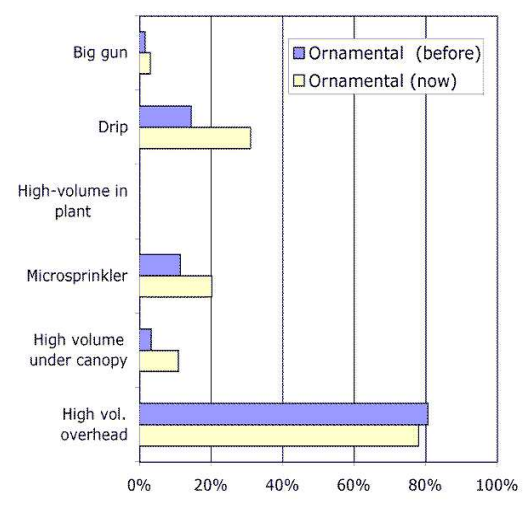

Figure 1. Changes in irrigation systems used by ornamental nursery producers with time. The term "before" denotes the irrigation system used when the grower first started farming and the "after" denotes the current irrigation system used. 
The use of high volume big gun irrigation has slightly increased. This probably reflects the preference in field nurseries for a mobile irrigation system that may be moved from field nursery to field nursery, reducing the need to establish a costly high volume solid-set system. In contrast, there was a doubling in the use of low volume irrigation systems, (i.e., drip, microsprinkler) from about $26 \%$ to $52 \%$. This is a reflection of the efficiency and versatility of these systems.

\section{Water resources}

The use of open, uncased wells has declined by $7.5 \%$ in the ornamental nursery operations surveyed (Fig. 2). The use of capped, cased wells has increased by $3 \%$ for the ornamental nursery $(46 \%$ before, $49 \%$ now) industry. The increased use of capped, cased wells for the ornamental nursery operations reflects the relatively permanent location of irrigation wells for these types of operations.

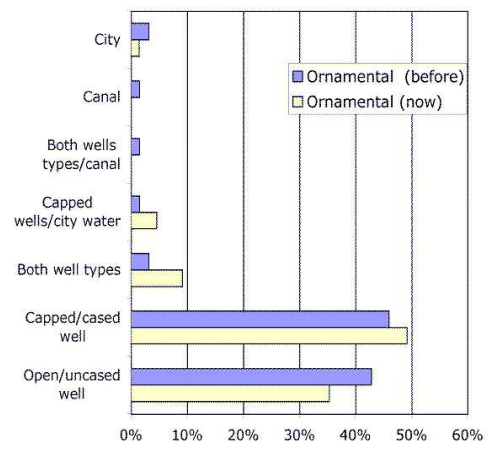

Figure 2. Changes in water sources used by ornamental nursery producers with time. The term "before" denotes the source of water used when the grower first started farming and the "after" denotes the current water source used for irrigation.

\section{Flooding and drought frequency}

Twenty-seven percent of the ornamental nursery operations surveyed experienced flooding within the last five years, and of those nurseries that reported flooding, $65 \%$ and $75 \%$ reported a reduction in yield and/or quality as a result of flooding. Nearly $44 \%$ of the ornamental nursery operations experienced drought sometime in the last five years. Of those operations experiencing drought, $25 \%$ and $47 \%$ reported a reduction in yield or commodity quality. Similarly, in a statewide nursery industry survey, about $56 \%$ of the nursery operations reported a dramatic decrease in sales due to drought (Hodges and Haydu, 2000), confirming drought as a major production problem in the ornamental nursery industry in Miami-Dade County.

\section{Water conservation practices, and the motivations for adopting them}

The survey included questions on the adoption of water conservation practices, and motivations for adopting them. Over $45 \%$ of the ornamental nursery operations surveyed use drip irrigation, with another $20 \%$ indicating they plan to use drip irrigation in the future. This includes both container and field nursery operations, many of which grow large specimens in containers or in the field, making use of low volume irrigation systems practical.

Over $45 \%$ of the ornamental producers reported growing drought tolerant plant species, and another $12 \%$ plan to do so in the future. Nearly $36 \%$ and $38 \%$ of the producers use, or plan to use, water saving devices, respectively. About two-thirds (66\%) of the nurseries reported monitoring soil moisture; but only $2 \%$ of these used any device, and the other $64 \%$ monitored moisture visually and by feel. Sixty-five percent monitor rainfall, and $63 \%$ monitor the weather to help determine their irrigation scheduling. Few $(8 \%)$ producers use the accounting method for scheduling irrigation. Over a third (34\%) of those surveyed reported irrigating at night, or early morning, or late evening to reduce evaporative losses; another $19 \%$ plan to practice this in the future. Nearly $11 \%$ of the producers currently capture rainwater for irrigation, and another 13\% plan to do so in the future. Only about $6 \%$ of the ornamental producers surveyed currently use water meters as a method to monitor and conserve water. However, $14 \%$ indicated they plan to incorporate this practice in the future.

Only $4.7 \%$ of the nursery operations have kept irrigation records, but another $20 \%$ plan to do so in the future. Twenty-five percent currently utilize the Mobile Irrigation Lab, and nearly $30 \%$ planned to use it in the future. This service is designed to assess the water and energy use efficiency of irrigation systems at no charge to producers. Recommendations for repairs and/or upgrades are provided in an effort to increase irrigation efficiency and conserve water. 
The three most common motivations for conserving water were savings in water, time, and money. The primary motivation varied slightly with each water conservation practice. However, the most consistently given primary reason was water savings, followed by money and time savings. Many times all three motivations were given equal weight.

\section{Conclusions and challenges ahead}

Our results generally show an increase in the adoption of water conservation practices in the Miami-Dade ornamental and nursery industries in the last 18 years. Drip irrigation systems were being utilized by about $45 \%$ of those surveyed. One- to two-thirds of the respondents reported periodic flooding and drought with a reduction in yield and product quality reported by over one-half of these respondents. The main reason for adoption of water conservation practices varied by water conservation practice, although the most consistently given reason was water savings.

In spite of these positive findings, there remain important educational challenges to optimize water use while protecting the environment (Muñoz-Carpena et al., 2003). Improvements are needed in four major areas:

1. Water delivery systems with the phase out of big-guns in field nurseries and increased use of low volume irrigation systems.

2. Improvements in water management practices including record keeping, equipment maintenance, use of soil water content monitoring devices, and periodic irrigation evaluation by the Mobile Irrigation Lab.

3. Protection of water sources by increased use of capped and cased wells.

4. Generalized adoption (and adaptation to the particular soils and climatic conditions of the area) of the Nursery and Container Grown Plants BMP Manual integrating improved water management.

\section{Literature cited}

Degner, R.L., T.J. Stevens, and K.L. Morgan. 2002a. Miami-Dade County Agricultural Land Retention Study, Summary and Recommendations, Vol. 1. Fla. Agri. Market Res. Center, IFAS, University of Florida, Gainesville, Fla. p. 89.

Degner, R.L., T.J. Stevens, and K.L. Morgan. 2002b. Miami-Dade County Agricultural Land Retention Study, Appendix B, Vol. 3. Fla. Agri. Market Res. Center, IFAS, University of Florida, Gainesville, Fla. p. 201.

Dillman, D.A. 2000. Mail and Internet Surveys: The Tailored Design Method. John Wiley and Sons, New York.

Donan, A.H., R. Kreutzwiser, and R. de Loë. 2000. Rural water use and conservation in southwestern Ontario. J. Soil and Water Conservation 55:161-171.

Garofalo, J., E.C. Worden, T. Frohne, and T. Stevens. 2002. Section 4: the commercial ornamental horticulture industry in Miami-Dade County. In: Degner, R.L., T.J. Stevens, and K.L. Morgan. Miami-Dade County Agricultural Land Retention Study, Appendix A, Vol. 2. Fla. Agri. Market Res. Center, IFAS, University of Florida, Gainesville, Fla. p. 110.

Hodges, A.W. and J.J. Haydu. 2000. Floridas environmental horticulture industry. Food and Resource Economics Dept., Fla. Coop. Ext. Service, Gainesville, Fla. P. 12.

Muñoz-Carpena, R., J. H. Crane, G.D. Israel and C. Yugalevitch. 2003. Water conservation survey of Miami-Dade County agricultural and golf course commercial water users. Proc. Fla State Hort. Soc. 116:(in press).

Nachmias D. and C. Nachmias. 1976. Research Methods in the Social Sciences. St. Martins Pres, New York.

Neuman, L.W. 1997. Social Research Methods: Qualitative and Quantitative Approaches. 3rd ed. Allyn and Bacon Publishers, Boston. 
SAS Institute Inc. (1999). SAS 8.01 [Computer software]. Cary, NC: SAS Institute Inc. 